\title{
AN ANALYSIS OF STUDENTS' ERROR IN CONSTRUCTING THE NEGATIVE AND INTERROGATIVE SENTENCE BY USING SIMPLE PRESENT TENSE
}

\author{
Diana Adinda Shafira ${ }^{1}$ \\ Universitas Prima Indonesia \\ Rabbayani Mawaddah ${ }^{2}$ \\ Universitas Prima Indonesia \\ Lidya Br Aritonang ${ }^{3}$ \\ Universitas Prima Indonesia \\ Elianti Nainggolan ${ }^{4}$ \\ Universitas Prima Indonesia \\ Natalia Widya Pasca Tarigan ${ }^{5}$ \\ Universitas Prima Indonesia \\ dianaadindashafira@gmail.com ${ }^{1}$
}

Submit, 02-12-2019 Accepted, 30-01-2020 Publish, 17-02-2020

\begin{abstract}
This research aims to find out the errors made by the students in constructing the negative and interrogative sentences by using the simple present tense. Those errors were classified into four types, namely omission, addition, misformation, and misordering based on surface strategy taxonomy from Daulay. The researchers used a descriptive qualitative method to find the result. The subject of this research was the VIII-A class of SMP Negeri 40 Medan that consisted of 30 students. The instrument for gathering the data was the essay test, which included 20 affirmative sentences, which asked to form those sentences into the negative and interrogative sentences. The findings indicated that the students' errors in this study were $318(50,4 \%)$ case of mistakes on misformation; $175(27,8 \%)$ case of errors on addition; $100(15,9 \%)$ case of errors on misordering; and $37(5,9 \%)$ case of errors on omission. It can be concluded that misformation in the most frequent errors, while failure is the rarest error in this research.
\end{abstract}

Keywords: error analysis, constructing negative and interrogative sentence 


\section{INTRODUCTION}

Language is crucial because it is one of the main ways to communicate and interact with other people around us. English is an example of the importance of language for people in many parts of the world.

According to Santillana (2013), English is the most used language in the world, and there are one out of ten people that can speak and understand English. English as the international language is an instance of the importance of a word, and it has been the language that most people use in the conversations of their daily life. Besides, English plays a significant role in many fields like engineering, business, medicine, and especially for education.

In many countries, some people who always use English as their daily language will have a different level of understanding than people who do not. Indonesia as an example. In this country, English is taught as a foreign language. It is not as easy as it looks for students to master English well. This is common for Indonesian students as English learners find it challenging to learn and use English since there are many language components and language skills which must be learned and mastered by students.

English teaching is focused on the ability of students to be capable of mastering the four language skills, namely: listening, reading, speaking, and writing (Depdibud, 2003). All of these skills are expected to be mastered by the students in school. But the are several factors that affect the process of studying. Those factors can be the teachers' technique in teaching, instruments used in the teaching-learning process, the conditions of the family, and many more. Students need to work hard and put effort into being able to master English. The differences in languages' structure between English and Bahasa might be the main reason why students often make errors in constructing a sentence.

One of the primary skills in writing. Writing can be defined as a process of transforming thoughts into the written language (Tiwari, 2005). Book is a communicating part that consents students to put their ideas and feelings on paper, to organize their insight and beliefs into convincing opinions, and to deliver meaning through well-constructed text.

In writing, the students still have confusion about grammar. Since grammar is the essential element of a knowledge or skill area, the forms and structural distinction between the Indonesian language and the English language can cause the students to make some English grammatical errors while trying to write an English text. It means that Indonesian students may find difficulties in using the correct English form and the right English structure.

According to Hidayah (2013), grammar is the system of rules governing the conventional arrangement and relationship of words in a sentence. It means that grammar is the guidance of writing for students to make the correct sentence. 
Grammar is known dominantly related to tense. In using English tenses, the students even have problems and often make errors in oral or written on the basic tense such as simple present tense. This kind of tense is used to describe habits, unchanging situations, and general truths. Students' errors in this tense can include the form of verb using of adverb and adjective, the lack of vocabulary, or even in making affirmative, negative, and interrogative sentences.

Generally, the simple present expresses situations or events that always exist, usually, habitually; they live now, have existed in the past, and probably will exist in the future (Azar, 2002). Often, the simple present tense is the first tense taught when students begin to learn about tense. This tense consists of three kinds of the sentence; they are affirmative, negative, and interrogative punishment. Its simple structure makes teachers hope that the students can easily understand it, with the use of verbs commonly found in daily life.

In constructing the negative and interrogative sentences, most of the students are confused. Some of them have many errors in their writing. They find it challenging to use the verb in the present, whether it's present tense singular or present tense plural. For example: "He does not bring the dictionary." "Does they come to my house?".'I do not do my homework".'"That man does not drive her son to school"."Do the cat steals your food?". And many more.

Based on the problem above, the researchers will conduct a study to find out what types of errors that students will make in constructing the negative and interrogative by using the simple present tense. The researchers will focus the material on simple present tense in creating the negative and interrogative sentence.

\section{LITERATURE REVIEW}

\section{Errors}

According to Brown (2000), failure is noticeable from the adult grammar of a native speaker, reflecting the interlanguage competence of the learner. By that statement, it can be concluded that errors are something to do with inappropriate forms of the grammar of the second language that has imprinted on learners' minds. Therefore, the learners can not be self-corrected because they do not have enough knowledge to distinguish their utterance or sentence. Correction is usually done by the teachers, such as teaching exercises, practices, remedial, and others. It is frequently said that errors are a description of students' understanding of the language system that they are learning. If the students' knowledge of the language system being studied is deficient, then the errors frequently occur. Those errors will decrease if the level of student understanding is getting increased (Tarigan, 2011). 
Corder (1981) stated that errors are the result of some failure of performance and differentiated errors from mistakes in the way that errors are systematically being errors of competence which occur in the continuum of the learning process. Based on those definitions above, the writer can define that error is an act or condition of ignorant or imprudent deviation from truth or accuracy.

\section{Causes of Errors}

According to Tarigan (2011), errors are not only made by students that are learning a second language but also by students who learn their first language. It shows that language errors are nearly related to language learning, both first language, and second language learning. Therefore, the mistakes that occur need to be known and studied more in-depth because these errors are an integral part of the language learning process. Setyawati (2010) states that there are several possible causes for students making an errors in language learning, they are (1) errors that are influenced by the language they have mastered first, (2) errors caused by lack of understanding of the language they use, and (3) errors caused by incorrect and imperfect language teaching.

\section{Types of Errors}

Dulay, Burt, \& Krashen (1982) classify four types of errors. They are based on linguistic category, surface strategy taxonomy, comparative taxonomy, and communicative effect taxonomy. In the surface strategy taxonomy, the errors are classified into four parts; they are omission, addition, misformation, and misordering.

\section{Error Analysis}

Muneera \& Shameen (2013) have contended that error analysis includes the study and analysis of the errors made by the learners of a second or a foreign language.

Khalid (2013) maintained that error analysis determines what a learner still needs to learn. It provides the necessary information about what is required in his or her competence.

According to Corder in Tarigan (2011), the analysis of language errors is a process, so some procedures must be followed as guidelines. The system goes through several stages, namely: (1) selecting parts of the language, (2) recognizing errors in the language sections, (3)classifying mistakes, (4)explaining mistakes, and (5) evaluating errors.

Thus, it can be said that the notion of error analysis is a process used by teachers and the researchers with the steps of data collection, identification of 
errors contained in the data, explanation of the errors, the classification of the errors based on their causes, and evaluation the level of the errors.

\section{Grammar}

Harmer (2001) defines syntax as the description of how words can change their form and can be combined into sentences in the language. According to Coghill \& Magendaz (2003) defines grammar as the set of rules that govern its structure. Grammar holds the role of determining how words are arranged to form meaningful units. In general, the grammar must be learned to master the four English language skills such as speaking, writing, reading, and listening correctly. From this classification, it seems that grammar plays a vital role in combining units of language to form sentences. The sentences are acceptable or grammatical if they follow the rules of grammar.

\section{Tenses}

The tenses are time concepts that embrace sentences. In English, the telling of an event will be significantly influenced by when it will take place. Prayitno (2002) states that tense refers to the form of the verb used; for example, He eats (simple present tense), he ate (simple past tense), he has eaten (present perfect tense), etc. While another definition from Hornby (1954) says that the word "tense" stands for a verb form or series of the verb used to express time relation.

Based on the opinion of the experts above, it is said that tenses are part of grammatical that explain the sentence about the occurrence of an event in the present, past, and future. This research will only discuss one primary tense; it is a simple present tense.

\section{Simple Present Tense}

According to Azar (2002) stating in the simple present tense that "in general, the simple present expresses events or situations that always exist, usually, habitually; they live now, have lived in the past, and probably will exist in the future.

The simple present tense can be divided into affirmative (positive), negative, and interrogative. Affirmative sentences are commonly referred to as positive sentences, which express the right conditions, such as 'The sky is blue.' Negative sentences have a negative meaning in a statement, usually marked with the addition of the word 'not' before the verb, for example, 'I do not like her.' The third, there is interrogative, commonly known as the question sentence. This sentence has two types; they are a Wh-question and Informative question. 
Based on Davidson (2004), there are several functions of simple present tense: 1) simple present tense expresses a fact or a thing that generally true e.g., Thalia works in the hospital, 2) simple present tense is used to talk about the repeated action e.g., I visit my grandparents twice a month, 3) simple present tense describes activities that are happening at the time. (It is used rather than the present continuous tense) e.g., Tasya drives a car. (a general fact: she knows how to drive a vehicle, or she often drives a vehicle.)4) simple present tense can be used to refer to future events and actions e.g., The tournament begins at 4 p.m.

\section{The Formula of Simple Present Tense}

\section{Verbal Sentence}

Verbal sentences express simple present tense sentences that use verbs. The verb forms have differences based on the type of subject. For $I$, you, we, they use the primary verb forms, while for the third singular subject such as he, she, it, the verbs used must be added with suffixes $-s$ or $-e s$. Adopted from Azar (2002), these are the formula of the verbal sentence:

Table 1 Formula of Verbal Sentence

\begin{tabular}{llll}
\hline Affirmative & $\mathrm{S}+\mathrm{V} 1(\mathrm{~s} / \mathrm{es})+\mathrm{O}$ & $\begin{array}{l}\text { Diana studies in Universitas } \\
\text { Prima }\end{array}$ & $\begin{array}{l}\text { Lunar eclipses occur three } \\
\text { times a year }\end{array}$ \\
\hline Negative & $\mathrm{S}+\mathrm{do} /$ does $+\mathrm{not}+$ & $\begin{array}{l}\text { Diana does not study in } \\
\mathrm{V} 1+\mathrm{O}\end{array}$ & $\begin{array}{l}\text { Universitas Prima } \\
\text { Lunar eclipses do not occur } \\
\text { three times a year }\end{array}$ \\
\hline \multirow{2}{*}{$\begin{array}{l}\text { Interrogative } \\
\text { Do/does }+\mathrm{S}+\mathrm{V} 1+\mathrm{O} \\
+?\end{array}$} & $\begin{array}{l}\text { Does Diana study at } \\
\text { Universitas Prima? } \\
\end{array}$ & $\begin{array}{l}\text { Do Lunar eclipses occur } \\
\text { three times a week? }\end{array}$ \\
\hline
\end{tabular}

\section{Nominal Sentence}

Nomina's sentence is a simple present tense that uses the verb 'be' such as is, am, are that are placed after the subject. Based on Guth (1961) in English, the present tense of 'be' is used to express some situation, such as 1) profession, trade occupation: Mrs. Sarah is a nurse, 2) nationally: Mr. Jokowi is an Indonesian, 3) size and shape: Finn is tall, 4) age: Ray is twenty years old, 5) characteristic: Mr. Yudha is diligent, 6) condition: Maria is sick, 7) place: The teacher is here, 8) color: This pouch is red. Azar (2002) also indicates this kind of sentence with 'be' as the main verbs have three basics of the formula: 
Table 2 Three Basic Formula

\begin{tabular}{lll}
\hline Affirmative & $\mathrm{S}+\mathrm{be}+\mathrm{Complement}$ & We are Indonesian \\
\hline Negative & $\mathrm{S}+\mathrm{not}+\mathrm{be}+\mathrm{We}$ are not Indonesian \\
& Complement & \\
\hline Interrogative & $\begin{array}{l}\mathrm{Be}+\mathrm{S}+\text { Complement } \\
+?\end{array}$ & Are we Indonesian? \\
\end{tabular}

\section{RESEARCH METHOD}

This study was designed in the form of descriptive qualitative research that was intended to accurately describe a phenomenon or problem that has been seen by researchers. This study also answers the common error problem found in students' writing, especially in literature or constructing the negative and interrogative sentences by using the simple present tense.

Data sources that were used in this study are students. The researchers focus on the eighth-grade students about the common types of errors and the dominant mistake made by them. In SMP Negeri 40 Medan, there are nine classes for the eighth-grade students. Because of the large population in this study, the researchers have chosen one of the types that are used as the sample to simplify the research. It was VIII-A that consisted of thirty students.

The writers gave the essay test for the students as the instruments of gathering information about students' errors in constructing and interrogative sentence by using the simple present tense - the reason for choosing the essay than the multiple choices because the errors would be seen more clearly. The test consisted of 20 affirmative sentences written using the simple present tense. And then, the students were asked to form those sentences into the negative and interrogative sentences. The duration of time give to complete the test was 60 minutes.

The data analysis was started after all the students' worksheets were collected. The researchers conducted some procedures in analyzing the students' errors. Firstly, identifying the errors by the students' answers and classifying the errors according to the Surface Strategy Taxonomy. They divide the error into errors of omission, addition, misformation, and misordering. Lastly, the researchers described the errors made by the student themselves and calculated the percentage of errors individually to find the dominant error.

\section{FINDINGS}

Data collection was conducted in SMP Negeri 40 Medan, which taken up from eight grade students. The researchers found the error results that were 
analyzed based on the surface strategy taxonomy by Dulay (1982) and classified them into errors of omission, errors of addition, inaccuracies of misformation, and errors of misordering.

The data was collected from thirty students in the VIII-A class. Each student was given a piece of paper that consisted of 20 affirmative sentences in simple present tense and must be written into the negative and interrogative sentences. It means 1200 total sentences have been analyzed. From the total of sentences, the researchers found 630 errors. Two steps analyzed data, they are identification and classification, as mentioned in the Research Method (Chapter II). After collecting the data, the errors were counted by using a table and calculated the number of each error.

Table 3 The Types of Students' Error

\begin{tabular}{cccccc}
\hline $\begin{array}{c}\text { Student's } \\
\text { Number }\end{array}$ & $\begin{array}{c}\text { Errors of } \\
\text { Omission }\end{array}$ & $\begin{array}{c}\text { Errors of } \\
\text { Addition }\end{array}$ & $\begin{array}{c}\text { Errors of } \\
\text { Misformation }\end{array}$ & $\begin{array}{c}\text { Errors of } \\
\text { Misordering }\end{array}$ & Total \\
\hline $\mathbf{1}$ & 2 & 24 & 2 & 17 & 45 \\
\hline $\mathbf{2}$ & 2 & 2 & 0 & 14 & 18 \\
\hline $\mathbf{3}$ & 3 & 20 & 3 & 11 & 37 \\
\hline $\mathbf{4}$ & 0 & 16 & 10 & 8 & 34 \\
\hline $\mathbf{5}$ & 0 & 0 & 14 & 0 & 14 \\
\hline $\mathbf{6}$ & 0 & 2 & 12 & 2 & 16 \\
\hline $\mathbf{7}$ & 0 & 2 & 12 & 2 & 16 \\
\hline $\mathbf{8}$ & 1 & 20 & 1 & 14 & 36 \\
\hline $\mathbf{9}$ & 0 & 0 & 14 & 0 & 14 \\
\hline $\mathbf{1 0}$ & 2 & 2 & 14 & 0 & 18 \\
\hline $\mathbf{1 1}$ & 3 & 0 & 14 & 0 & 17 \\
\hline $\mathbf{1 2}$ & 0 & 16 & 8 & 8 & 32 \\
\hline $\mathbf{1 3}$ & 2 & 4 & 15 & 1 & 22 \\
\hline $\mathbf{1 4}$ & 0 & 12 & 4 & 10 & 26 \\
\hline $\mathbf{1 5}$ & 0 & 0 & 14 & 0 & 14 \\
\hline $\mathbf{1 6}$ & 2 & 2 & 14 & 0 & 18 \\
\hline $\mathbf{1 7}$ & 0 & 0 & 14 & 0 & 14 \\
\hline $\mathbf{1 8}$ & 0 & 0 & 14 & 0 & 14 \\
\hline $\mathbf{1 9}$ & 2 & 0 & 14 & 0 & 16 \\
\hline $\mathbf{2 0}$ & 1 & 1 & 13 & 0 & 15 \\
\hline $\mathbf{2 1}$ & 2 & 6 & 14 & 1 & 23 \\
\hline $\mathbf{2 2}$ & 3 & 2 & 14 & 0 & 19 \\
\hline $\mathbf{2 3}$ & 0 & 14 & 12 & 2 & 28 \\
\hline & & & & & \\
\hline & 0 & 0 & 0 & 0 & 2 \\
\hline
\end{tabular}




\begin{tabular}{cccccc}
\hline $\mathbf{2 4}$ & 3 & 4 & 13 & 1 & 21 \\
\hline $\mathbf{2 5}$ & 0 & 0 & 16 & 0 & 16 \\
\hline $\mathbf{2 6}$ & 0 & 3 & 14 & 0 & 17 \\
\hline $\mathbf{2 7}$ & 5 & 7 & 10 & 2 & 24 \\
\hline $\mathbf{2 8}$ & 1 & 15 & 12 & 7 & 35 \\
\hline $\mathbf{2 9}$ & 1 & 1 & 3 & 0 & 5 \\
\hline $\mathbf{3 0}$ & 2 & 0 & 4 & 0 & 6 \\
\hline Total & $\mathbf{3 7}$ & $\mathbf{1 7 5}$ & $\mathbf{3 1 8}$ & $\mathbf{1 0 0}$ & $\mathbf{6 3 0}$ \\
\hline Percentage & $\mathbf{5 , 9 \%}$ & $\mathbf{2 7 , 8 \%}$ & $\mathbf{5 0 , 4 \%}$ & $\mathbf{1 5 , 9 \%}$ & $\mathbf{1 0 0 \%}$ \\
\hline
\end{tabular}

The table above shows that the total number of errors made by students in constructing the negative and interrogative sentences was 630 errors. From the calculation of the data, it could be seen that the dominant error made by the students was errors in misformation with the total number of 318 errors $(50,4 \%)$. The second standard error was the errors of addition with 175 errors $(27,8 \%)$. The third was the errors of misordering with 100 errors $(15,9 \%)$, and the last one was the errors of omission with 37 errors $(5,9 \%)$.

The researchers analyzed the error of this research based on Dulay's theory, as known as surface strategy taxonomy. There are four types of a mistake made by students, namely omission, addition, misformation and misordering.

\section{Errors of Omission}

The omission is an error caused by the absence of an item that must appear in the form of utterance or sentence. The number of these errors was 37 errors or $5,9 \%$. These errors happen because some students omit an item that must be presented in the utterance or sentence. The example of omission based on students' worksheet: 1) she does eat delicious cookies, 2) we the best scout team? The revised sentences should be: 1) she does not eat delicious cookies (Because it should be written in the negative form), 2) are we the best scout team?

\section{Errors of Addition}

The addition is an error caused by the appearance of an item that must not present in the form of utterance or sentence. The number of these errors was 175 errors or $27,8 \%$. This error happens because students add a word or a group of words where should not be existed in the utterance or sentence. The example of addition based on students' worksheets: 1) Rina does not watch television regularly; 2) I do not want a good listener. The revised sentences should be: 1) Rina does not watch TV daily; 2) I am not a good listener.

\section{Errors of Misformation}


Misformation is characterized by the use of the wrong form of a morpheme or the structure. The number of these errors was 318 errors or $50,4 \%$. This kind of error happens when students use the wrong structure instead of the right one in the utterance or sentence. The example of misformation based on students' worksheets: 1) Rico and Rica do not twins, 2) does she an actress in Hollywood?. The revised sentenced should be: 1) Rico and Rica are twins, 2) is she an actress in Hollywood?

\section{Errors of Misordering}

Misordering is an error caused by the incorrect placement of a morpheme or a group of morphemes in an utterance or a sentence. The number of these errors was 100 errors or $15,9 \%$. These errors happen because the students are not able to arrange the right sentence. The example of misordering based on students' worksheets: 1) she does want to be a singer? 2) my does father drink tea every morning. It should be: 1) does she want to be a singer? (Because in the form of interrogative, does should be placed in the first sentence)2) my father does not drink tea every morning.

\section{DISCUSSION}

The classifying of error was made into four types based on the theory of Dulay et al. (1982). The formula for analyzing the data was also used to count the percentage of each type of errors. Those errors are omission, this percentage of errors was 5,9\%, which had 37 number of errors, an addition was 27,8\% with 175 total of errors, misformation was 50,4\% with 318 errors, and misordering was $15,9 \%$ with 100 errors.

After identifying the error in constructing the negative and interrogative sentences by using the simple present tense, the data obtained were the errors found in misformation as the major of error. Maniar (2017), as the earlier researcher, was recognized as the same result that misformation was the most frequent error found in that research. For this research, misformation is the dominant error, which has a total error of 318 errors or $50,4 \%$. This is because the students were not able to determine the structures in the simple present tense. The addition is another common error found in students' worksheets. It is because students still add a word or a group of words where should not be existed in the sentence.

Meanwhile, misordering is found in some students' worksheet because of the incorrect placement of a morpheme or a group of morphemes in the sentences. The last is omission as the most infrequently errors did by the students. Moreover, the students could not distinguish the nominal and verbal sentences. It can be said that all students produce errors due to a lack of understanding of writing lessons, 
even for the basic lessons for the second grade of junior high school students. It can be seen from the students' worksheets in constructing the negative and interrogative on nominal sentences.

\section{CONCLUSION}

Based on the findings of the data analysis, the researchers have drawn some conclusions as follows: The types of errors that were made by the eighthgrade students are errors of omission, errors of addition, errors of misformation and errors of misordering. The error that dominantly made by the eighth-grade students of SMP Negeri 40 Medan is misformation, followed by addition, misordering, and omission sequentially.

\section{REFERENCES}

Azar, B., S. (2002). Understanding and Using English Grammar.Third Edition. New York: Longman.

Brown (2000). Principle of Language Learning and Teaching. New York: Longman.

Coghill, J \& Stacy, M. (2003). English Grammar. New York: WileyPublishing, Inc.

Corder, S., P. (1981). Error Analysis and Interlanguage. London: Oxford University.

Davidson, G. (2004). Verbs and Tenses. Singapore: Learners Publishing Pte Ltd.

Departmen Pendidikan \& Kebudayaan. (2003). Kurikulum Berbasis Kompetensi: Garis-Garis Besar Program Pengajaran Bahasa Inggris. Jakarta: Departmen Pendidikan dan Kebudayaan, Direktorat Jendral Pendidikan Dasar dan Menengah.

Dulay, Heidi C., Burt, Marina K., \& Krashen, S., D. (1982). Language Two.New York: Oxford University Press.

Guth, H. P. (1961). Words and Ideas. California: Wordsworth Publishing Company, Inc.

Harmer, J. (2001). The Practice of English Language Teaching: Young Learner. New York: Pearson Education Limited.

Hidayah, A. T. (2013). Error Analysis on The Use of The Simple Tense and The Simple Past Tense in Writing Essay Among TESL College Students. International Journal of Education and Research, 1(12), 1-12.

Hornby, A. S. 1954. A Guide To Pattern And Usage In English. London: Oxford University Press.

Khalid, M. A. (2013). Investigating Jordanian EFL Students' Spelling Errors at Tertiary Level. International Journal of Linguistics. 5 (3). 164-176.

Maniar, A. S. (2017). An Analysis of Students' Error In Constructing Negative and Interrogative Sentence By Using Simple Past Tense. Medan: Universitas Prima, Indonesia.

Muneera \& Shameem. (2013). Error Analysis of Present Simple Tense in the Interlanguage of Adult Arab English Language Learners. English Language Teaching. 6 (2). 146-154. 
Prayitno, A. M. (2002). Mastering English Grammar. Surabaya: Sarana Ilmu Surabaya.

Santillana, C. (2013). 10 Reasons to Learn English. Experience English. Real Experience Group.

Setyawati, N. (2010). Analisis Kesalahan Berbahasa Indonesia: Teori dan Praktik. Surakarta: Yuma Pustaka.

Tarigan, H.,G. (2011). Pengajaran Analisis Kesalahan Berbahasa. Bandung:Angkasa.

Tiwari, D. (2005). Encyclopedia of Modern Methods of Teaching 7. New Delhi: Crescent. 